\title{
The Effect of Motivation, Competency and Organizational Learning towards Global Mindset (Study of PUC Employees on Competitive in AFTA 2015)
}

\author{
Grace Amin ${ }^{1, *}$, Genoveva Claudia ${ }^{2}$ \\ ${ }^{1}$ Management Study Program, Faculty of Business, President University, Indonesia \\ ${ }^{2}$ Management Study Program, Faculty of Business, President University, Cikarang, Indonesia
}

Copyright $\bigcirc 2016$ by authors, all rights reserved. Authors agree that this article remains permanently open access under the terms of the Creative Commons Attribution License 4.0 International License

\begin{abstract}
In 2015, the countries of South East Asia will be entering to the free market. In order to be competitive, every company must prepare themselves well, including PUC as one of international educational institutions. The objectives of this research are to determine the effect of motivation, competency and organizational learning towards global mindset. In this research, the researcher used quantitative approach. Data were collected by structure questionnaire distributed to 98 respondents. Descriptive statistics, classical assumption, multiple regression test, hypothesis test which included T-test (partial test) and F-test (simultaneously test) were employed to analyze data. Based on the analysis of data, it can be concluded that from the 4 hypothesis, 2 of them significant hypotheses
\end{abstract}

Keywords Motivation, Competency, Organizational Learning, Global Mindset

\section{Introduction}

Preparing for ASEAN economics community in 2015, countries from Southest Asia should have competitive advantage. To be able to compete, countries in Southeast Asia must be prepared with a variety of advantages. Indonesia is one of the countries located in Southeast Asia and has a great opportunity to contribute to the economy in Southeast Asia. With the greatest number of people, this is a potential point for Indonesia. Although Indonesia has large number of population but if they are not accompanied by good quality, they will face many difficulties to compete with other countries in Southeast Asia.

PUC is one of Indonesian universities with international standard that was established in 2001. PUC has been recruiting foreign students from various countries, such as countries from Southeast Asia region. PUC use 100 percent of English in all of student's activities. All of employees who are recruited also prepared to be able to speak English and provide international standards services.

According Yende (2011)[12] in order to survive, a company in the face of global competition, the employees should be competent, able to compete and have a good performance. The same thing concluded by Emmanuel (2010) [4], which examines the professors in a college about their readiness compete globally. Emmanuel concluded that the initiative of professors is a significant effect on motivation and their global insight.

With the free market in Southeast Asia (AFTA), access to the cooperation and recruitment of prospective students will be more easily. These opportunities must be accompanied by the readiness of employees to compete. The readiness of employees can be seen from the motivation, competence and organizational learning.

Motivation is a needs-satisfying process, which means that when person's needs are satisfied by certain factors, the person will exert superior effort toward attaining organizational goals (Robbins, 2001) [9]. Based on Vroom (1964)[11], people are motivated by how much they want something. Motivation leads to efforts and the efforts combined with employees' ability, which determine the work performance.

Based on the above problems, the researchers wanted to examine how the motivation of employees, if they have the motivation to work better in the global competition. The second variable is the competence, whether employees have the knowledge, skills and attitudes as well as behaviors that support the global competition? The third variable is the organization learning, whether employees have the readiness to learn, improve the ways of working, open-minded and have a vision for the future? While the independent variable in this study is a global mindset.

\section{Literature Review}




\subsection{Motivation}

Motivation can be defined as those forces within individual that push or propel someone to satisfy basic needs or wants (Yorks, 1976) [9]. Motivators are the factors that arouse, direct and sustain increased performance (Duttweiler, 1986) [9].

There are numerous motivational theories, they are concerned with individual needs and goals, and identify the specific reasons and factors to shown that why human need motivation, and how to motivate human (Buchbinder \& Shanks, 2012)[2].

Some famous motivational theories are Maslow's Hierarchy of Needs Theory and Herzberg's Two-Factor Theory. Maslow hypothesized that within every human being, there exists a hierarchy of five needs (Robbins,2001)[9] :

1. Physiological. Include hunger, thirst, shelter and other bodily needs

2. Safety. Security and protection from physical and emotional harm.

3. Social. Affection, belongingness, acceptance and friendship.

4. Esteem. Internal factors such as self respect, autonomy, and achievement.

5. Self-actualization. Drive to become what we are capable of becoming; includes growth, achieving our potential and self-fulfillment

The two factors theory is a theory that relates intrinsic factorsto job satisfaction and associates extrinsic factors with dissatisfaction. It also called motivation - hygiene theory (Robbins, 2001)[9].

Managing a group of people with different personalities is never easy. But if you're managing or leading a team, it's essential to know what motivates your people, how they respond to feedback and praise, and what tasks fit them well. David McClellands has proposed a theory of motivation that is closely associated with learning concepts. David McClelland's Human Motivation Theory gives us a way of identifying people's motivating drivers. Human Motivation Theory by McClelland can help organization to know member's main motivational driver, give praise and feedback effectively, assign employes suitable tasks, structure feedback for the person and keep them motivated.

McClelland's Human Motivation Theory proposes that when a need is strong in a person, it's effect is motivate the person to use behavior which leads to satisfaction of the need. This theory identified three motivators that McClelland believed we all have: a need for achievement, a need for affiliation, and a need for power. People will have different characteristics depending on their dominant motivator. These motivators are learned, largely dependent on our culture and life experiences and one of these will be our dominant motivating driver. Since needs are learned, behavior which is rewarded tends to recur at a higher frequency (Gibson, Ivancevich and Donnelly, 1979) [13].

\section{a. Need for achievement}

The need for achievement involves the desire to independently master objects, ideas and other people, and to increase one's self-esteem through the exercise of one's talent. (Wallace, Goldstein and Nathan, 1987)[13]

Employees who have a strong need for achievement are motivated by jobs that are challenging and over which they have some control, whereas employees who have minimal achievement needs are more satisfied when jobs involve little challenge and have a high probability of success.

People motivated by achievement need challenging, but not impossible, projects. They thrive on overcoming difficult problems or situations, so make sure you keep them engaged this way. People motivated by achievement work very effectively either alone or with other high achievers. When providing feedback, give achievers a fair and balanced appraisal. They want to know what they're doing right - and wrong - so that they can improve.

\section{b. Need for affiliation}

Need to be part of something and want to develop relationship and desire a friendship. People motivated by affiliation work best in a group environment, so try to integrate them with a team (versus working alone) whenever possible. They also don't like uncertainty and risk. Therefore, when assigning projects or tasks, save the risky ones for other people.

When providing feedback to these people, be personal. It's still important to give balanced feedback, but if you start your appraisal by emphasizing their good working relationship and your trust in them, they'll likely be more open to what you say. Remember that these people often don't want to stand out, so it might be best to praise them in private rather than in front of others.

\section{c. Need for power}

Those with a high need for power work best when they're in charge. Because they enjoy competition, they do well with goal-oriented projects or tasks. They may also be very effective in negotiations or in situations in which another party must be convinced of an idea or goal. When providing feedback, be direct with these team members. And keep them motivated by helping them further their career goals.

\subsection{Competency}

The competency - based approach has become integral in Human Resources Management. Competency comes from a Latin word meaning "suitable" (Bueno \& Tubbs, 2004) [14].

Competency is defined as a person's underlying characteristics related to the effectiveness and individual performance on the job (Levenson, 2006; Ozcelik, 2006)[14]. Spencer and Spencer (1993) [14] defined competency as an individual prominent characteristics that can predict behavior and performance that is effective or superior in the work situation.

Spencer and Spencer (1993)[14] identified five types of competency characteristics : 


\section{a. Motives}

Motives are the things that an individual consistently thinks about or wants that stimulate action. Motives direct, drive and select behavior toward certain goals or actions.

\section{b. Traits}

Traits are physical characteristics and consistent responses to situation or information.

\section{c. Self-concept}

Self-concept is an individual's attitudes, values or self-image.

\section{d. Knowledge}

Knowledge is the information that and individual has in specific content areas.

\section{e. Skills}

Ability to perform a certain physical or mental task.

Knowledge and skill competencies tend to be visible, easy to develop and relatively surface characteristics, whereas motives, traits and self-concept are more hidden, deeper and central to personality. Knowledge and skill are relatively easy to train and it's the most cost-effective way to secure those employee abilities. Visible competencies maybe somewhat technical competencies basically required by the job, whereas hidden competencies are behavioral competencies that drive an individual's performance in the job (Spencer and Spencer, 1993)[10].

\subsection{Organizational Learning}

There are many definitions exist concerning organizational learning. According to Fiol \& Lyles (1985)[15] organizational learning is the process of improving actions through better knowledge and understanding. Organizational learning occurs with an organization skilled at creating, acquiring and transferring knowledge and at modifying it's behavior to reflect new knowledge and insights (Garvin, 1993)[15]. Nevis, DiBella \& Gould (1995)[15] explain organizational learning as the capacity or processes within an organization to maintain or improve performance based on experience.

Cultivating a learning culture may indeed become one of the primary means to attain and maintain a competitive advantage (Sinkula, Baker and Noordewier, 1997)[16]. Sinkula, Baker and Noordewier (1997)[16] also argue that the success of learning activities should be addressed by performance measure. A learning orientation is significantly related to business performance (Baker and Sinkula, 1999)[16]. Organizational learning is a critical process of developing market knowledge and a driving force of action in an governance of, market - oriented organization (Sinkula, 1994)[16].

There are four principal schools of organizational learning research :

\section{a. Economic view}

Focus on the learning that accrues with continous production. Experience yields tacit knowledge, which in turn provides the basis for a reduction in production costs. No distiction is made between lower and higher order learning but attention is implicitly focused on the former.

\section{b. Developmental view}

The focus of this view is on higher order learning and the stages that must be followed to achieve such learning; has a distinctly linear, stepwise conception. Learning proceeds in a series of interlinked sequences that provide the necessary foundation for moving to each successive stage. Each stage is associated with a qualitatively different sort of learning.

\section{c. Managerial view}

The managerial view focuses on higher order learning as developmental view, but it doesn't see the achievement of such learning as having to progress through a hierarchical sequence. The key to achieving higher order of learning is to follow a set of prescriptive guidelines that will change the organization's culture.

\section{d. Process view}

Process view focuses on all forms of learning, be it lower order or higher order, and in particular on the fundamental processes that underpin learning, regardless of nature and style. Organizational learning is conceptualized in terms of the processes of information acquisition, dissemination and utilization.

Each view has a distinctive focus of interest and each differs in term of its assessment of what is required to achieve organizational learning. According to Sinkula (1997)[16], the process view is evident in the measurement of the information - processing variables of acquisition and dissemination, and the recognition of interpretation and memory within their conceptual model. The managerial view is the evident in the reference to those "organizational values that influence the propensity of the firm to create and use knowledge".

\subsection{Global Mindset}

Global mindset has emerged as a necessary attribute for effective global leadership for years (Pucik \& Saba,1998; Kedia \& Mukherji, 1999; Oddou, Mendenhall \& Richie, 2000)[10]. The foundation of the construct of global mindset started by Perlmutter (1969)[10] who defined three orientations that managers have used in managing a multinational corporation: ethnocentric (home country orientation), polycentric (host country orientation) and geocentric (world orientation). Global or geocentric organizations are complex and interdependent, aim for a collaborative approach between headquarters and subsidiaries, have standards which are universal and local, try to reach local and global objectives and develop the best 
individuals in the world for key positions.

Rhinesmith(1992)[10] defined global mindset as an identity or paradigm for viewing the world holistically. People with global mindset drive for the broader picture, accept the complexity of the world, trust process more than structure, value diversity and cultural differences, are comfortable with change, surprise and ambiguities, and constantly re-examine themselves and their boundaries. They are knowledgeable about their business and industry in both domestic and foreign context, have high conceptual ability, are flexible, able to tackle uncertainty well, seek ways to learn and develop themselves. They must be able to manage competitiveness, complexity, adaptability, teams, uncertainty and learning.

Bleechler and Javidan (2007)[10] described global mindset as a person's knowledge, cognitive ability and psychological attributes that allowed people to lead in different cultural environments. There are three major components of global mindset based on this theory. They are intellectual capital (global leader's intellectual and cognitive capabilities), psychological capital (psychological makeup that enables global leaders to put their knowledge into use) and social capital (relationship inside and outside organization).

\section{Research Model and Hypothesis}

\subsection{Theoretical Framework}

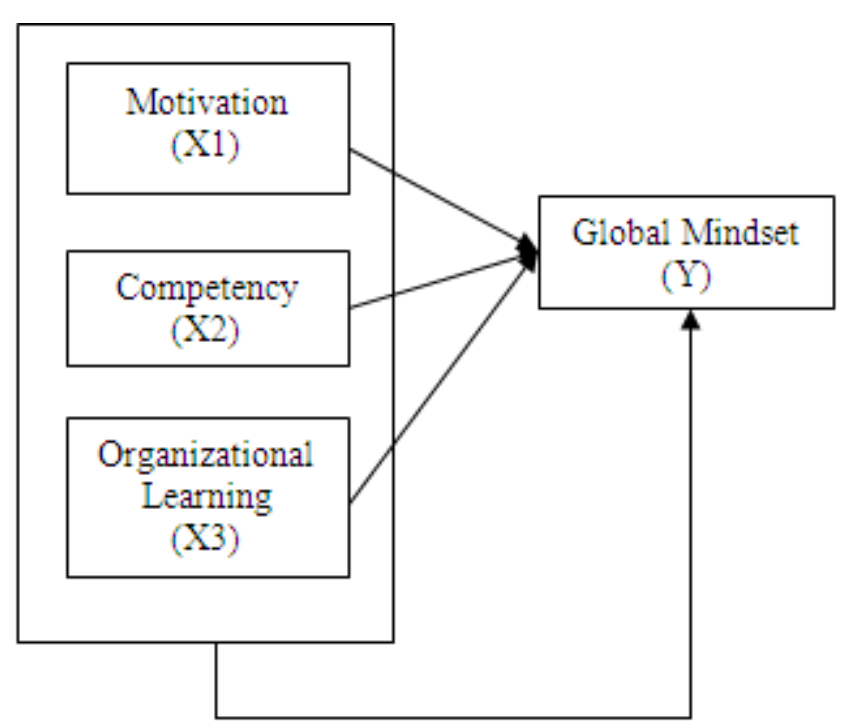

H1 $=$ There is significant influence between motivation and global mindset

$\mathbf{H 2}=$ There is significant influence between competency and global mindset

H3 = There is significant influence between organizational learning and global mindset

H4 = There is significant influence between motivation, competency and organizational learning toward global mindset.

\subsection{Research Design}

In this research, the researcher is using quantitative method to analyze the influence between motivation, competency, organizational learning toward global mindset.

\subsection{Population and Sample}

Population refers to the entire group of people, events, or things of interest that the researcher wishes to investigate. A population where all the elements are easily countable can be considered as finite and a population where all the elements are not easily countable as infinite (Sekaran, 2003).

In this research, researchers use PUC's employees as the population. Researchers use Slovin's theory and get 98 employees as the sample.

\subsection{Multiple Regression Analysis}

Multiple regressions is one of a general method for describing the relationship between a continuous outcome variable (dependent) and one or multiple variable (independent) in one equation (Salam, 2008). In this research, researcher use more than two variables, thus researcher use multiple regression analysis as the statistical tool. The form of multiple regression analysis is :

$$
\mathrm{Y}=\mathrm{b} 0+\mathrm{b} 1 \mathrm{X} 1+\mathrm{b} 2 \mathrm{X} 2+\mathrm{b} 3 \mathrm{X} 3+\mathrm{e}
$$

Where :

$$
\begin{array}{ll}
\mathrm{Y} & =\text { Global Mindset } \\
\mathrm{b} 0 \quad=\text { regression constant } \\
\mathrm{b} 1, \mathrm{~b} 2, \mathrm{~b} 3 & =\text { regression coefficients } \\
\mathrm{X} 1 & =\text { Motivation } \\
\mathrm{X} 2 & =\text { Competency } \\
\mathrm{X} 3 & =\text { Organizational Learning }
\end{array}
$$

\section{Result}

\subsection{Hypothesis}

\subsection{Data of Respondents}


Table 1. Data of respondents

\begin{tabular}{|c|c|}
\hline Categories & Percentage \\
\hline Male & $64 \%$ \\
\hline Female & $36 \%$ \\
\hline $17-27$ years old & $33 \%$ \\
\hline$>27-37$ years old & $45 \%$ \\
\hline$>37-47$ years old & $14 \%$ \\
\hline$>47$ years old & $8 \%$ \\
\hline Post graduated & $36 \%$ \\
\hline Under graduated & $48 \%$ \\
\hline Diploma & $8 \%$ \\
\hline Senior High School & $8 \%$ \\
\hline Lecturer & $33 \%$ \\
\hline Staff & $67 \%$ \\
\hline $1-3$ years & $55 \%$ \\
\hline$>3-6$ years & $24 \%$ \\
\hline$>6-9$ years & $16 \%$ \\
\hline$>9$ years & $5 \%$ \\
\hline &
\end{tabular}

\subsection{Multiple Regression}

This research already fullfilled validity, realibility and classical assumption test.

$\mathrm{T}$ test basically shows whether each or partial of independent variables have an influence on the dependent variable. In this research, researcher will use t test in order to determine whether Global Mindset is influenced by Motivation, Competency and Organizational Learning and each of independent variable will be tested partially.

Based on table 2 below, it can be seen that all of independent variables (Motivation, Competency and Organizational Learning) have positive effect on Global Mindset. Although all of independent variables have a positive effect, there is only one variable that is a significant (Organizational Learning) because the significance level lower than $0.05(\mathrm{t}=0.000)$.

Table 2. T Test

\begin{tabular}{|c|c|c|c|c|c|c|}
\hline \multirow[t]{2}{*}{ Mode } & & \multicolumn{2}{|c|}{ Unstandardized Coefficients } & \multirow{2}{*}{$\begin{array}{c}\begin{array}{c}\text { Standardized } \\
\text { Coefficients }\end{array} \\
\text { Beta }\end{array}$} & \multirow[b]{2}{*}{$t$} & \multirow[b]{2}{*}{ Sig. } \\
\hline & & $B$ & Std. Error & & & \\
\hline \multirow[t]{4}{*}{1} & (Constant) & 6.745 & 3.792 & & 1.779 & .079 \\
\hline & MOV & .181 & .101 & .148 & 1.795 & .076 \\
\hline & $\mathrm{COM}$ & .098 & .089 & .104 & 1.100 & .274 \\
\hline & ORG & .537 & .088 & .577 & 6.107 & .000 \\
\hline
\end{tabular}

(Source : questionnaire, prossesed by SPSS)

From the table 2, if written in the standardized coefficients form of the equation, the regression is as follows:

Global Mindset $=6,745+0.181$ Motivation + 0.099 Competency +0.537 Organizational Learning

Based on this research, the $\mathrm{F}$ value is 36.537 which is greater than $F$ table $(\mathrm{df}=96, \alpha=0.05)$ is 2.309 and Significance value is $0.000^{\mathrm{a}}$, which is less than 0.05 , it indicates that the Global Mindset significance by Motivation, Competency and Organizational Learning.

Based on table 3 below, it shows that the Coefficient Correlation ( $\mathrm{R}$ ) is equal $52.4 \%$ of the variation that occurs in the Global Mindset is explained by all of the independent variables (Motivation, Competency and Organizational Learning ) while the rest $47.6 \%$ are explained by factors other than the research variables.

Table 3. Coefficient Correlation

Model Summary

\begin{tabular}{|l|l|l|r|r|}
\hline Model & $\mathrm{R}$ & $\mathrm{R}$ Square & \multicolumn{1}{c|}{$\begin{array}{c}\text { Adjusted R } \\
\text { Square }\end{array}$} & $\begin{array}{c}\text { Std. Error of } \\
\text { the Estimate }\end{array}$ \\
\hline 1 & $.734^{\mathrm{a}}$ & .538 & .524 & 3.547 \\
\hline
\end{tabular}

a. Predictors: (Constant), ORG, MOV, COM

(Source : questionnaire, prossesed by SPSS)

\subsection{Research Results}

The findings of this research are organizational learning has significant influence toward global mindset while motivation and competency has no influence on global midset. It means if organizational learning is increasing, the employees' global mindset also will be increasing.

\section{Conclusions}

Simultaneously, Motivational Variables, Competency and Organizational Learning has a significant influence on Global Mindset. Organizational learning has significant influence towards global mindset, while motivation and competency have no influence on Global Mindset.

\subsection{Managerial Implications}

Based on the conclusions, the organizational learning has a significant influence towards global mindset, so organization has to improve it by providing good facilities and giving traning to the employee so they can improve their performance.

Dimension "need of power" from Motivation variable have the lowest score than the others dimensions, so improve the leadership mindset can be as a company concern. In this research, giving the idea, making decision and taking as a leader are not as employees' culture. The company can arrange the leadership training for internalization the leadership mindset.

The dimension "improve knowledge and skills" from competency variable has the lowest score than the others; it means that the employees have not effort for improving their knowledge and skills. The company can create the reward system for the employees who have the creativity for get the job target. 


\section{REFERENCES}

[1] Arora, Pallvi and Neelu Rohmetra. 2013. Culturally Intelligent Organizations: Towards Success in Global Business World, Twelfth ALMS International Conference on Management.

[2] Buchbinder, S.B. \& Shanks, N.H. (2012). Introduction to Health Care Management, $2^{\text {nd }}$ Edition. London: Jones and Bartlett publishers

[3] Cooper, Donald R and Pamela S. Schindler.2014. Business Reseach Method, Twelfth Edition, New York: McGraw-Hill Irwin.

[4] Emmanuel, Jean Franqois. 2010. Motivational Factors and Worldview Dimensions Associated With perceptions of Global Education Initiative by U.S. College Professors. University of South Florida.

[5] Juanda, Bambang. 2009. Research Methodology of Economics and Business, Bogor : IPB Press.

[6] Maholtra, Naresh K. 2010. Marketing Research an Applied Orientation, Fifth edition, New Jersey : Perarson Education.

[7] Martin, James Haven. 2002. Motivational Processes and Performance: The Role of Global and Facet Personality Traits. University of North Carolina at Chapel Hill.

[8] Robbins, S. P. (2001). Organizational Behavior, $9^{\text {th }}$ Edition. Prentice Hall

[9] Story, Joana S. 2010. Testing The Impact of Global Mindset on Positive Organizational Outcomes: A Multi-Level Analysis. University of Nebraska as Lincoln, http://digitalcommons.unl.edu/aglecdiss.

[10] Vroom, V.H. (1964). Work and motivation. New York: Wiley

[11] Yende, Nhlanhla Promise. 2011. The Key Global Mindset factors Affecting Competitiveness and Performance of South African Soft Drinks Companies. Gordon Institute of Business Science

[12] http://files.eric.ed.gov/fulltext/ED316767.pdf

[13] http://blogs.wayne.edu/ioadventures/files/2013/12/Competen cies-and-Competecny-Model-A-Brief-Overview-of-its-Deve lopment-and-Application.pdf

[14] http://www.jstor.org/stable/258048?seq=2\#page_scan_tab_co ntents

[15] http://citeseerx.ist.psu.edu/viewdoc/download?doi=10.1.1.12 $3.147 \&$ rep $=$ rep $1 \&$ type $=$ pdf 